\title{
Pengaruh Penggunaan Gadget dan Pola Asuh Islami terhadap Mental Spiritual Siswa
}

\author{
Ahmad Solehudin ${ }^{1}$ Benny Prasetiya ${ }^{2}$ Heri Rifhan Halili ${ }^{3}$ \\ Sekolah Tinggi Agama Islam Muhammadiyah Probolinggo \\ * Corresponding Author. E-mail: \\ ahmad.solehudin1710@gmail.com,prasetiyabenny@gmail.co \\ m,heririfhan@yahoo.com
}

Receive: $13 / 07 / 2021$

Accepted: 23/08/2021

Published: 04/10/2021

\begin{abstract}
Abstrak
Penulis melakukan penelitian ini dengan tujuan mengetahui berapa besar pengaruh 2 variabel bebas yaitu Gadget sebagai X1 dan Pola Asuh Islami sebagai X2 terhadap 1 variabel bebas yaitu Mental Spiritual Siswa sebagai Y. Penelitian dilakukan menggunakan metode kuantitatif yang mengumpulkan data melalui angka-angka dari hasil survei angket yang disebarkan melalui via google form. Objek dalam penelitian merupakan siswa SMP Islam Terpadu Permata Kota Probolinggo. Hasil penelitian menunjukkan bahwa Gadget (X1) dan Pola Asuh Islami (X2) memiliki pengaruh sebesar 5,5\% terhadap Mental Spiritual Siswa (Y).
\end{abstract}

Kata kunci: gadget, pola asuh islami, mental spiritual siswa

\section{Abstract}

The author conducted this study with the aim the 2 independent variables, namely the Gadget as X1 and Islamic Parent as X2, on the 1 independent variable, namely the Mental Spirit as Y. The study was conducted using a quantitative method that collected data through the figures from the results of the questionnaire survey distributed via google form. The object of the research is the students of SMP Islamic Permata, Probolinggo City. The results showed that the Gadget (X1) and Islamic Parent (X2) had an effect of 5,5\% on the Mental Spirit (Y)

Keywords: gadgets, islamic parent, mental spirit 


\section{Pendahuluan}

Remaja ialah orang yang berproses dari masa anak-anak ke masa dewasa Su'ud (Su'ud, 2011). Masa perkembangan manusia yang paling pesat yaitu di masa remaja. Pada usia remaja anak cenderung mempunyai rasa penasaran yang tinggi menurut (Hardiyanto et al., 2018).

Menurut (Viandari \& Susilawati, 2019)Dengan berkembangnya tehnologi, banyak sarana yg oleh manusia dijadikan alat untuk mempermudah berkomunikasi dan berinteraksi, salah satunya adalah gadget. Gadget ialah perangkat elektronik berukuran kecil yang mempunyai fungsi khusus, seperti handphone (smartphone) (Kurniawati, 2020). Salah satu penyebab yang dapat mempengaruhi perkembangan perilaku maupun mental remaja adalah gadget.

Tanpa kontrol orangtua, khususnya diri sendiri, hal ini dapat mengakibatkan mereka terjerumus pada kenakalan remaja, akibatnya tingkat penyimpangan sosial remaja lumayan besar, antara lain minumminuman keras serta gambling (Nur Utami \& Raharjo, 2019). bahkan ada sebagian anak muda yang memakai salah satu aplikasi yang bisa open BO( Booking Out). Hal ini dapat membuat perbahan besar terhadap psikologis kebatinan anak muda.

Mental seorang remaja yang kacau, hidupnya tidak akan tenang, jiwanya akan terusik, alhasil bisa memunculkan konflik hati bahkan setres. Perihal ini dapat menimbulkan emosi yang negatif, alhasil ia tidak akan sanggup menggapai kematangan jiwa, gampang putus asa, dan kemungkinan besar bisa bunuh diri. Sedangkan orang yang mentalnya positif akan sebaliknya, ia mempunyai keyakinan yang kokoh bahwa setiap hal yg ia jalani akan memberi pelajaran yg berharga yg akan mengantarnya menuju kesuksesan yang memuaskan.

Oleh karena itu, sangat penting bagi orangtua memberi perhatian serta pola asuh islami pada anak-anaknya dengan baik, karna hal itu akan berpengaruh dan menjadi nilai lebih dalam membentuk mental spiritual anak. Sebab mental spiritual yang sehat serta kembali pada jalur agama, seseorang dapat mengontrol diri, khususnya untuk para anak muda yang penuh dengan tantangan serta cenderung suka mencoba hal yang baru.

\section{Metode Penelitian}

\section{Jenis Penelitian}

Metode atau Tata cara yang dipakai dalam riset ini merupakan tata cara riset kuantitatif yang menggunakan analisa data dari perolehan survei angket melalui via google form menggunakan aplikasi SPSS 21. Tata cara atau metode riset kuantitatif ialah riset yang memakai angka-angka dalam analisa data hasil penelitiannya.

Menurut (Suliyanto, 2017) Pendekatan kuantitatif ialah pendekatan yang bermaksud buat mencoba filosofi, membuat kenyataan, membuktikan ikatan variabel, membagikan cerita statistik, menghargai serta berspekulasi hasilnya.

Riset ini terbagi beberapa variabel yaitu : 1. Independent variable (X1) 2. Independent variable(X2) Dependent variable (Y). Variabel $\mathrm{X}$ merupakan sebab adanya dependen, dan variable dependen merupakan variabel yang menjadi akibat. Dalam riset ini, yang termasuk variabel independen (variable bebas) adalah gadget dan pola asuh islami. Sedangkan variable dependent (variabel terikat) dalam riset ini adalah mental spiritual.

Populasi adalah subjek yang telah terpenuhi kriterianya, yang telah ditetapkan atau jumlah keseluruhan yang akan diteliti dari beberapa individu (Darmawan, 2019). Siswa di SMP Islam Terpadu Permata kota Probolinggo tersebut menjadi populasi dalam riset ini, namun tidak akan digunakan seluruhnya, karena teringat sedikitnya waktu dan anggaran peneliti.

Sampel ialah bagian dari populasi guna menggantikan populasi dalam penelitian (Sampel \& Nurlaila, n.d.). Dalam riset ini metode sampling yang dipakai ialah 
nonprobability sampling dengan metode purposive sampling. Penulis menggunakan Teknik Purposive Sampling, karena penulis telah memilih siswa kelas VIII di SMP Islam Terpadu Permata. Siswa kelas VIII telah dipilih oleh penulis karena kualitas siswanya menunjang atau memenuhi kriteria untuk menjawab pertanyaan di rumusan masalah. Adapun jumlah siswa kelas VIII di SMP Islam Terpadu Permata adalah sebanyak 40 siswa.

Instrument dalam riset ini memakai uji gadget, pola asuh islami dan mental spiritual. Saat sebelum uji dicoba, terlebih dulu dicoba keabsahan serta reabilitas. Dalam riset ini analisa informasi dicoba dengan memakai statistik ialah: Regresi simpel serta jamak, hubungan simpel, parsial, serta jamak seluruh pengukuran dicoba pada derajat signifikansi 0, 05 .

\section{Pembahasan}

\section{Gadget terhadap Mental}

Spiritual

Pengaruh kemajuan teknologi( gadget) telah ada semenjak era modern. Dan masih banyak dampak negatif akibat Konsumsi Jejaring Sosial, bahkan kita sendiri juga tidak dapat terlepas dari internet menurut (Chusna, 2017). Sosial media pastinya menghilangkan batasanbatasan warga untuk bersosialisasi, batas ruang ataupun waktu (Nurmalasari \& Wulandari, 2018). Dengan media sosial ini membuat masyarakat diperankan untuk saling berkomunikasi tanpa batasan jarak dan tempat (Febrino, 2017).

\section{Dampak Negatif \\ gadget,} diantaranya adalah :

a. Menghabiskan waktu dengan sia-sia Anak- anak yang biasanya bisa mengisi waktu bermain dengan aktifitas yang bisa dimanfaatkan untuk perkembangan otaknya, tapi dengan gadget ia bisa lupa diri dan lupa waktu, sehingga ia akan sibuk didunia gadget itu sendiri (Uyun, 2020).

b. Pemakaian gadget yang sangat lama dalam kegiatan tiap hari akan membatasi kemajuan serta kesehatan otak, dan membatasi keahlian dalam mengungkapkan pikirannya.

c. Terdapat fitur ataupun aplikasi yang tidak cocok dengan usia anak, terlebih lagi dengan kurangnnya nilai norma, etika, bimbingan serta agama dapat menyebakan anak melakukan sikap menyimpang (Syahudin, 2019).

d. Mengganggu Kesehatan Mata

Dengan rentan waktu dan jarak yang tak terkontrol, gadget bisa mengganggu kesehatan mata karena radiasi yang terdapat pada gadget sangatlah tinggi (Subarkah, 2019)

e. Menjadikan mereka suka menyendiri, tertutup serta membatasi diri dari interaksi sosialnya. Entah di hari libur dan akhir pekan, mereka lebih memilih main gadget darpada main dengan temannya (Mentari, 2020).

f. Mengganggu Konsentrasi Belajar Gadget mempunyai sebagian fitur yang canggih semacam kamera, film, permainan, dan lain- lain (Benny et al., 2019). Sebagian fitur itu bisa mengusik proses belajar mengajar disekolah ketika KBM( Kegiatan Belajar Mengajar) berjalan. Misal, saat guru menjelaskan pelajaran, anak didik justru bermain gadget atau digunakan untuk hal-hal yang tak wajar saat diluar pengawasan orang tua diluar area rumah (Kurniawati, 2020).

Dampak adanya Covid 19, karena Kegiatan Belajar Mengajar (KBM) dilakukan secara online, Hasil observasi di SMP IT Permata, peneliti mendapati beberapa penemuan diantaranya tenaga pendidik (guru), masih ada guru yang kurang maksimal dalam melaksanakan proses pembelajaran, para pendidik masih sangat terbatas dalam pengembangan materi, pada saat menyampaikan materi guru hanya fokus dengan satu arah dan model ceramah 
sehingga siswa cenderung merasakan kebosanan.

Masalah selanjutnya yaitu kurangnya penjagaan atau kontrol dari orangtua untuk penggunaan gadget. Jadi, terkadang setelah KBM selesai siswa masih beralasan sibuk mengerjakan tugas dari sekolah. Padahal kenyataannya ia menggunakan gadget untuk main game, nonton drakor, bermain tik tok, dan media sosial lainnya. Sehingga membuat mereka menjadi malas untuk melakukan kegiatan yang berkaitan dengan mental spiritual (Subarkah, 2019).

Penulis melakukan riset ini, ialah agar tahu Pengaruh Penggunaan Gadget terhadap Mental Spiritual Siswa di SMP IT Permata kota Probolinggo.

\section{Pola Asuh Islami Orangtua terhadap Mental Spiritual}

Pola asuh Islami ialah sikap dan perilaku orangtua terhadap anak semenjak dini, dari tahap mengajarkan, membina, menyesuikan dan mendidik anak yang mengacu pada Al- Qur' an dan al- Hadits (Asuh et al., 2017).

Pola asuh Islami ialah pola membimbing dengan syariat Islami yang berasal dari ajaran Islam. Menurut (Prasetyaningrum, 2012) Aspek targetnya ialah terpenuhinya semua keahlian orang yakni: ruh, ide serta badan, alhasil menjadikan anak yang balance (tawazun). Orang tua yakni pendidik pertama yang dikenali oleh anak. Orang tua diberi amanah untuk mendidik anaknya menjadi ahli agama (Padjrin, 2016).

Wujud Identifikasi ajaran agama pada anak semenjak dini akan mempengaruhi proses pemahaman serta pengalaman agama pada diri anak menurut (Uyuni, 2019). Oleh Sebab itu, Rasullah memposisikan orang tua sebagai penentu bagi pembentukan ahlak anak. Pola asuh orang tua kepada buah hatinya amatlah memastikan serta mempengaruhi karakter anak menurut (Munte, 2013).
Anak menjadi baik ataupun tidak semua tergantung dari cara membimbing orangtua dalam keluarga menurut (Nur Utami \& Raharjo, 2019). Tujuan dari pola asuh islami yaitu terciptanya penerus muslim dan mukmin yang berkepribadian kuat dan berahlakul karimah hingga menjadikan mental spiritual mereka menjadi baik (Anisah, 2011).

\section{Gadget dan Pola Asuh Islami terhadap Mental Spiritual}

Dalam perspektif Islam, dimensi kebatinan atau spiritual selalu berkaitan langsung dengan Tuhan Yang Maha Satu ( tauhid). Antusiasme ialah tutur dasar Spiritual yang berarti daya, daya antusias, tenaga, akhlak, ataupun motivasi menurut (Wig, 1999). Kebatinan berhubungan dengan arwah, antusias ataupun jiwa, yang berkaitan dengan agama, keagamaan, serta keimanan (Iman et al., 2020).

Penulis bisa merumuskan kalau mental spiritual merupakan suatu yang berhubungan dengan keadaaan psikologis kebatinan ataupun jiwa seorang yang melukiskan sesuatu aksi, tindakan ataupun aksi laris yang selaras ataupun cocok dengan anutan agama Islam.

Pemakaian teknologi gadget dikala ini, pada dasarnya mempunyai akibat positif serta negatif untuk anak, di antara lain dalam pembuatan pola pikir anak, ialah bisa menolong anak untuk menata kecekatan bermainnya, membuat strategi serta analisa dalam game, juga bisa menolong anak dalam meningkatkan keahlian otak kanan sepanjang dalam pengawasan yang ketat oleh orangtua menurut (Subarkah, 2019). Dari sebagian dampak positif diatas, bila diawasi lebih lanjut hingga aspek berkuasa lebih ke arah akibat negatif yang mempengaruhi pada psikologis spiritual anak (Mentari, 2020).

Pemakaian gadget pada anak umumnya diakibatkan sebab tuntutan profesi orangtua yang padat jadwalnya. Alhasil perhatian orangtua kepada anak jadi kurang, serta orangtua biasanya 
memberikan anak gadget agar menghiburnya supaya anak tidak rewel (Chusna, 2017). Dulu orang yang sanggup membeli gadget hanya orang kalangan menengah ke atas, namun pada faktanya saat ini orangtua yang berpendapatan seadanya, sanggup membeli gadget untuk anaknya (Syahudin, 2019). Banyak golongan anak muda yang memakai gadget untuk hal yang tidak penting. Sebaliknya cuma sedikit sekali yang memakainya untuk komunikasi dengan orang tua mereka ataupun untuk melihat video pembelajaran (Febrino, 2017).

Pembahasan tentang pola membimbing dalam Islam sesungguhnya ialah hal yang telah dibahas dalam kaidah Islam. Islam telah

mengajarkan, bahwasanya melatih serta mendidik anak ialah sesuatu keharusan untuk seorang mukmin, sebab anak ialah titipan yang wajib dipertanggungjawabkan oleh orangtua (Daulay, 2014).

Oleh sebab itu, segala hal yang telah dilatih oleh orangtua tentu mempengaruhi kepada perkembangan karakter anak. Peran orangtua dapat melingkupi beberapa kemampuan anak, ialah emosional, raga, sosial, kognitif, serta mental spiritual (Firdausi, 2017). Kelima perihal itu yang harus dilatih oleh orangtua agar menjadikan anak yang shalih serta shalihah. Dalam kondisi kebudayaan Islam Indonesia, hingga pola membimbing orangtua berakibat kepada sosial anak di dalam bentuk keluarga yang beraneka ragam karakternya, serta bersumber pada angka kebudayaan Islam Indonesia, maka hendak menghasilkan mental spiritual anak yang bagus sertapatuh(Ayun,2017).

\section{Deskripsi Data Hasil Penelitian}

Penelitian ini dilakukan untuk mengetahui pengaruh dari 2 variabel bebas terhadap 1variabel terikat. Adapun variabel bebas tersebut adalah Gadget yang menjadi X1, Pola Asuh Islami sebagai X2, sedangkan Mental Spiritual yang menjadi Y. Data diperoleh dari hasil penghitungan angka pada survei angket dengan nilai berikut:

\begin{tabular}{|c|c|}
\hline Alternatif jawaban & Nilai \\
\hline Selalu (SL) & 4 \\
\hline Sering (S) & 3 \\
\hline Kadang-kadang (K) & 2 \\
\hline Tidak Pernah (TP) & 1 \\
\hline
\end{tabular}

\section{Pengujian Persyaratan Analisis}

\section{Uji Normalitas}

Uji coba normalitas tujuannya yaitu untuk mengetahui wajar atau tidak wajarnya suatu penyaluran informasi atau data. Guna melaksanakan uji normalitas dengan memakai uji kolmogorof-Smirnov menurut Benny (Prasetiya, 2019), ialah apabila asymp.Sig atau $\boldsymbol{P}$, value $>0,05$, membuktikan bahwa data tersebut normal. Hasil uji normalitas variabel pada riset ini, bisa disimak pada tabel 1 .

Tabel 1.1

\section{Uji Normalitas}

\begin{tabular}{|c|c|c|c|c|}
\hline & & GADGET & POLAASUH & MENTAL \\
\hline $\mathrm{N}$ & & 40 & 40 & 40 \\
\hline \multirow[t]{2}{*}{ Normal Parameters ${ }^{a, b}$} & Mean & 36,38 & 45,08 & 44,05 \\
\hline & Std. Deviation & 3,585 & 4,393 & 4,935 \\
\hline \multirow[t]{3}{*}{ Most Extreme Differences } & Absolute & 119 & ,208 &, 096 \\
\hline & Positive & ,081 & ,131 & .064 \\
\hline & Negative &,- 119 &,- 208 &,- 096 \\
\hline Kolmogorov-Smirnov Z & &, 754 & 1,318 & 607 \\
\hline Asymp. Sig. (2-tailed) & & 621 &, 062 & .855 \\
\hline
\end{tabular}

Tabel 1.1 menunjukkan perolehan hasil Asymp. Sig (2-tailed) Gadget (X1) ialah 0,621, hasil Asymp. Sig (2-tailed) Pola Asuh Islami (X2) ialah 0,62 dan nilai Asymp. Sig (2-tailed) Mental Spiritual (Y) ialah 0,855 dimana ketiga nilai Asymp. Sig (2-tailed) yang diperoleh tersebut $>0,05$. Perolehan hasil ketiga variabel menunjukkan bahwa 
masing-masing data yang digunakan berdistribusi normal.

\section{Uji Linieritas}

Dasar penentuan hasil uji linearitas menurut Benny(Prasetiya, n.d.) adalah seumpama hasil sig Deviation from Linearity > dari 0,05, maka ada kaitan linear bersignifikan antar variabel. Uji linearitas yang digunakan dalam pengujian kali ini ialah:

a. Uji linearitas pertama: Gadget (X1) dengan Mental Spiritual (Y).

b. Uji linearitas kedua: Pola Asuh Islami (X2) dengan Mental Spiritual (Y). Perolehan uji linearitas pertama bisa disimak pada tabel 2.1

\section{Tabel 2.1 Uji Linearitas Gadget (X1)} dengan Mental Spiritual (Y)

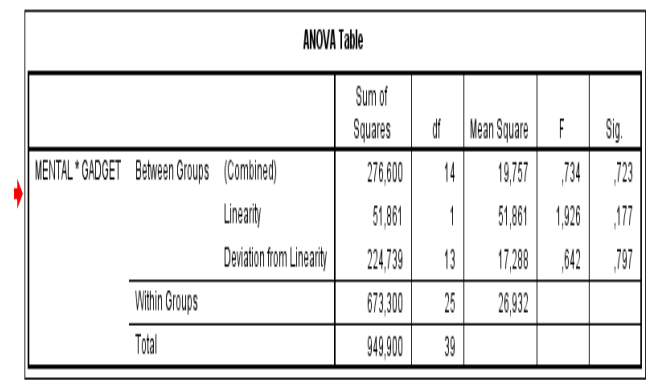

Tabel 2.1 dapat diketahui bahwa nilai sig Deviation from Linearity yang diperoleh 0,797 berarti > dari 0,05. Melalui hasil perolehan tersebut, diketahui terdapat hubungan yang signifikan antara Gadget (X1) dengan Mental Spiritual (Y). Perolehan hasil pengujian selanjutnya dapat disimak pada tabel 2.2

\section{Tabel 2.2 Uji Linearitas Pola Asuh Islami (X2) dengan Mental Spiritual(Y)}

ANOVA Table

\begin{tabular}{|c|c|c|c|c|c|c|c|}
\hline & & & $\begin{array}{l}\text { Sum of } \\
\text { Squares }\end{array}$ & $d f$ & Mean Square & $\mathrm{F}$ & Sig. \\
\hline \multirow[t]{5}{*}{ MENTAL" POLAASUH } & \multirow[t]{3}{*}{ Between Groups } & (Combined) & 143,010 & 13 & 11,001 &, 354 & .973 \\
\hline & & Linearity & .634 & 1 & .634 & .020 & .887 \\
\hline & & Deviation from Linearity & 142,375 & 12 & 11,865 &, 382 & .958 \\
\hline & \multicolumn{2}{|l|}{ Within Groups } & 806,890 & 26 & 31,034 & & \\
\hline & \multicolumn{2}{|l|}{ Total } & 949,900 & 39 & & & \\
\hline
\end{tabular}

Dari tabel 2.2 dapat diketahui bahwa nilai sig Deviation from Linearity yang diperoleh 0,958 berarti $>$ dari 0,05. Melalui hasil perolehan diatas, diketahui ada kaitan bersignifikan antara Pola Asuh Islami (X2) dengan Mental Spiritual (Y). Selanjutnya ketiga variabel akan diuji kembali dengan uji multikolinearitas yang bertujuan untuk mengetahuia apakan terjadi multikolinearitas atau kaitan yang kuat antar variabel bebas yang ada dalam sebuah regresi. Dasar penentuannya ialah nilai Tolerance > dari 0,10, dan perolehan nilai VIF < dari 10,00. Berikut hasil yang diperoleh.

Tabel 3 Uji multikorelasi

\begin{tabular}{|c|c|c|c|c|c|c|c|}
\hline \multicolumn{8}{|c|}{ Coefficients $^{a}$} \\
\hline \multirow[b]{2}{*}{ Model } & \multicolumn{2}{|c|}{ Unstandardized Coefficients } & \multirow{2}{*}{$\begin{array}{c}\begin{array}{c}\text { Standardized } \\
\text { Coefficients }\end{array} \\
\text { Beta }\end{array}$} & \multirow[b]{2}{*}{$t$} & \multirow[b]{2}{*}{ Sig. } & \multicolumn{2}{|c|}{ Collinearity Statistics } \\
\hline & $B$ & Std. Error & & & & Tolerance & VIF \\
\hline (Constant) & 32,753 & 10,644 & & 3,077 & .004 & & \\
\hline GADGET & ,324 & .223 & .235 & 1,454 &, 154 &, 978 & 1,023 \\
\hline POLAASUH &,- 010 & 182 & -009 & $-0,058$ & .954 & 978 & 1,023 \\
\hline
\end{tabular}

Tabel 3.1 menunjukkan nilai Tolerance 0,978 berarti > dari 0,10 dan perolehan VIF 1,023 berarti < dari 10,00. Melalui hasil perolehan dari pengujian diketahui bahwasanya variabel bebas dalam regresi ganda tidak terjadi multikolinearitas.

\section{Uji Hipotesis}

Hipotesis ialah suatu gambaran peneliti tentang hasil penelitian yang dilakukan. Untuk mengetahui diterima atau tidaknya sebuah huipotesis harus dilakukan pengujian terlebih dahulu. Dasar pengambilan hasil uji hipotesis ialah perolehan $R$ Square dikali dengan 100\% akan menunjukkan seberapa besar 
pengaruh. Beberapa hipotesis pada riset ini ialah:

a. Hipotesis pertama:

- $\mathrm{H}_{0}$ : Tidak terdapat pengaruh bersignifikan dari Gadget (X1) terhadap Mental Spiritual (Y).

- $\mathrm{H}_{\mathrm{a}}$ : Terdapat pengaruh bersignifikan dari Gadget (X1) terhadap Mental Spiritual (Y).

b. Hipotesis kedua:

- $\mathrm{H}_{0}$ : Tidak terdapat pengaruh bersignifikan dari Pola Asuh Islami (X2) terhadap Mental Spiritual (Y).

- $\mathrm{H}_{\mathrm{a}}$ : Terdapat pengaruh bersignifikan dari Pola Asuh Islami (X2) terhadap Mental Spiritual (Y).

c. Hipotesis ketiga:

- $\mathrm{H}_{0}$ : Tidak terdapat pengaruh bersignifikan dari Gadget (X1) dan Pola Asuh Islami (X2) terhadap Mental Spiritual (Y).

- $\mathrm{H}_{\mathrm{a}}$ : Terdapat pengaruh bersignifikan dari Gadget (X1) dan Pola Asuh Islami (X2) terhadap Mental Spiritual (Y).

Uji hipotesis yang pertama adalah pengujian Gadget terhadap Mental Spiritual. Hasil uji hipotesis pertama bisa disimak di tabel 4.1

\section{Tabel 4.1 Uji Hipotesis Gadget (X1) terhadap Mental Spiritual (Y)}

\begin{tabular}{|c|c|c|c|c|}
\hline \multicolumn{5}{|c|}{ Model Summary } \\
\hline Model & $\mathrm{R}$ & R Square & $\begin{array}{c}\text { Adjusted R } \\
\text { Square }\end{array}$ & $\begin{array}{l}\text { Std. Error of } \\
\text { the Estimate }\end{array}$ \\
\hline 1 & $234^{\mathrm{a}}$ &, 055 &, 030 & 4,861 \\
\hline
\end{tabular}

\begin{tabular}{|ll|r|r|r|r|c|}
\multicolumn{7}{|c|}{ ANOVA $^{\text {a }}$} \\
\hline Model & & $\begin{array}{c}\text { Sum of } \\
\text { Squares }\end{array}$ & \multicolumn{1}{c|}{ df } & Mean Square & F & Sig. \\
\hline 1 & Regression & 51,861 & 1 & 51,861 & 2,194 &, $147^{\text {b }}$ \\
& Residual & 898,039 & 38 & 23,633 & & \\
& Total & 949,900 & 39 & & & \\
\hline
\end{tabular}

Dependent Variable: MENTAL

b. Predictors: (Constant), GADGET

Tabel 4.1 menunjukkan perolehan nilai $R$ Square ialah 0,055 berarti apabila dikali dengan 100\% menjadi 5,5\%. Hasil tersebut menunjukkan bahwa Gadget (X1) ada pengaruh terhadap Mental Spiritual (Y). Sedangkan sisa 94,5\% pengaruh berasal dari faktor lain. Hal tersebut mengartikan diterimanya $\mathrm{H}_{\mathrm{a}}$ dan ditolaknya $\mathrm{H}_{0}$. Uji hipotesis selanjutnya bisa disimak di tabel 4.2

\section{Tabel 4.2 Uji Hipotesis Pola Asuh Islami} (X2) terhadap Mental Spiritual (Y)

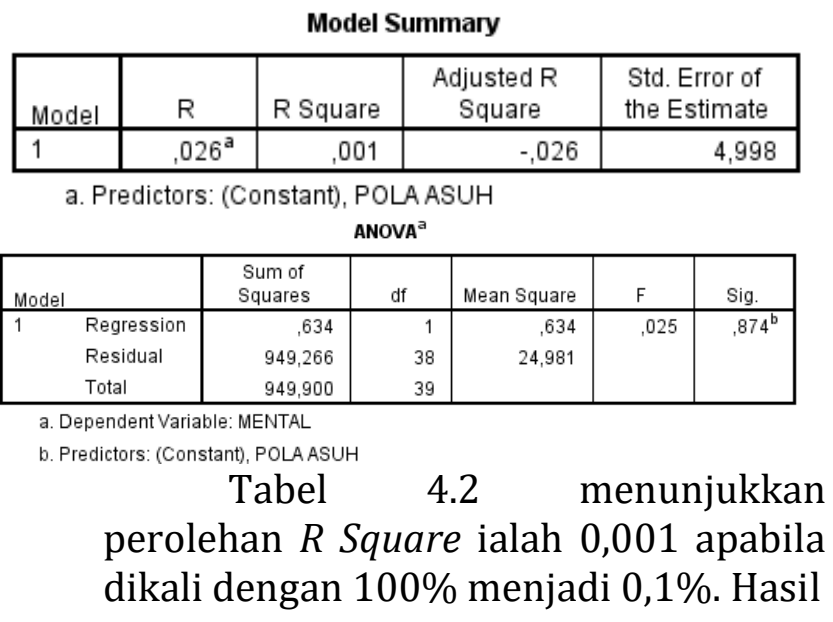

tersebut menunjukkan bahwa Pola Asuh Islami (X2) ada pengaruh terhadap Mental Spiritual (Y). Sedangkan sisa 99,9\% pengaruh berasal dari faktor lain. Hal tersebut mengartikan diterimanya $\mathrm{H}_{\mathrm{a}}$ dan ditolaknya $\mathrm{H}_{0}$. Perolehan uji hipotesis ketiga bisa disimak di tabel 4.3

Tabel 4.3 Uji Hipotesis Gadget dan Pola Asuh Islami (X2) terhadap Mental Spiritual (Y)

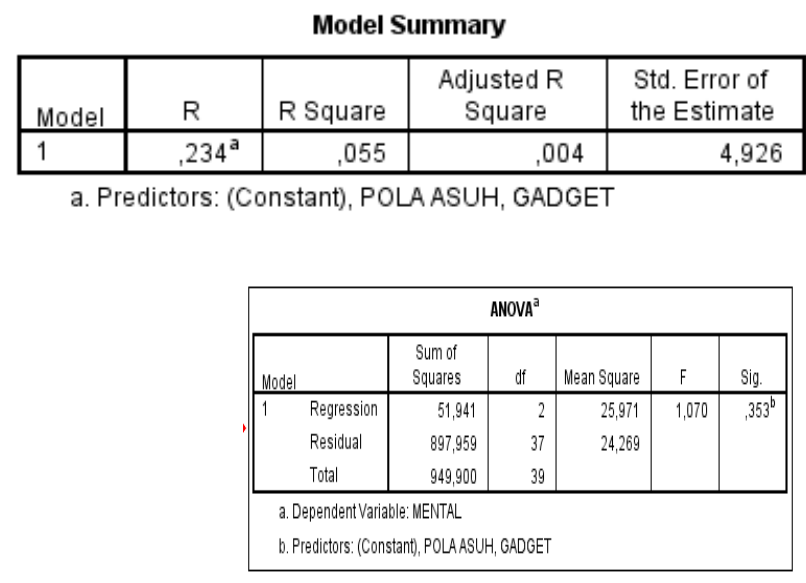

Tabel 4.3 menunjukkan perolehan $R$ Square 0,055 apabila dikali 
dengan 100\% menjadi 5,5\%. Hasil kaitan bersignifikan pada Pola Asuh Islami (X2) tersebut menunjukkan bahwa Gadget dengan Mental Spiritual (Y).

(X1) dan Pola Asuh Islami(X2) ada pengaruh terhadap Mental Spiritual (Y). Sedangkan sisa 94,5\% pengaruh berasal dari faktor lain. Hal tersebut mengartikan diterimanya $\mathrm{H}_{\mathrm{a}}$ dan ditolaknya $\mathrm{H}_{0}$.

\section{Kesimpulan}

Hasil perolehan dalam setiap pengujian pada riset ini akan menjelaskan apakah data berdistribusi normal, linier dan terdapat pengaruh bersignifikan antara variabel bebas pada variabel terikat yang ada. Pengujian yang dilakukan dalam proses analisa data adalah uji normalitas dan uji linearitas. Dasar penentuan hasil nilai yang diperoleh dalam uji normalitas menggunakan uji kolmogrof smirnov adalah perolehan Asymp. Sig (2-tailed) > 0,05 berarti berdistribusi normal.

Nilai perolehan menunjukkan Asymp. Sig (2-tailed) Gadget (X1) ialah 0,621, Asymp. Sig (2-tailed) Pola Asuh Islami (X2) 0,62 dan Asymp. Sig (2-tailed) Mental Spiritual (Y) 0,855 dimana ketiga Asymp. Sig (2-tailed) yang diperoleh tersebut $>0,05$. Hasil perolehan ketiga variabel tersebut mengartikan bahwasanya masing-masing data yang digunakan berdistribusi normal.

Pengujian selanjutnya adalah uji linearitas yang dilakukan melalui 3 tahapan dengan dasar penilaian hasil apabila sig Deviation from linearity $>0,05$, berarti data memiliki kaitan yang linier bersignifikan. Tahap uji linearitas yang pertama yaitu uji linearitas antara Gadget (X1) dan Mental Spiritual (Y) dengan perolehan nilai sig Deviation from Linearity yang diperoleh ialah $0,797>0,05$. Perolehan tersebut mengartikan terdapat kaitan bersignifikan pada Gadget (X1) dengan Mental Spiritual (Y). Tahap uji linearitas kedua adalah pengujian antara Pola Asuh Islami (X2) dan Mental Spiritual (Y) dengan perolehan nilai sig Deviation from Linearity 0,958 > dari 0,05. Perolehan itu mengartikan bahwa adanya
Tahap ketiga dalam uji linearitas yaitu uji multikolinearitas anatara ketiga variabel yang ada. Dasar penilain hasil adalah jika Tolerance $>0,10$ dan perolehan VIF $<10,00$ artinya data tak mengalami multikolinearitas antara variabel $X$. Dari pengujian ini didapat hasil perolehan Tolerance 0,978 $>0,10$ dan perolehan VIF $1,023<10,00$. Kedua hasil yang diperoleh mengartikan bahwasanya tidak ada multikolinearitas antara variabel X.

Setelah itu merujuk dasar ketentuan perolehan nilai $R$ Square yang kemudian dikali dengan $100 \%$ dalam uji hipotesis. Pada uji hipotesis pertama $R$ Square 0,055 atau 5,5\%, mengartikan bahwa Gadget (X1) memiliki pengaruh yang kecil terhadap Mental Spiritual (Y).

Perolehan uji hipotesis kedua $R$ Square 0,001 atau $0,1 \%$, menngartikan bahwa Pola Asuh Islami (X2) memiliki pengaruh yang kecil sebesar $0,1 \%$ terhadap Mental Spiritual (Y). Sedangkan uji hipotesis ketiga $R$ Square 0,055 atau 5,5\%, mengartikan Gadget (X1) dan Pola Asuh Islami (X2) memiliki pengaruh yang kecil terhadap Mental Spiritual (Y). Ketiga uji hipotesis yang telah dilakukan menolak masing-masing $\mathrm{H}_{0}$ dan menerima masing-masing $\mathrm{H}_{\mathrm{a}}$ yang ada.

Dari hasil ketiga hipotesis, bisa diambil kesimpulan yaitu ada pengaruh pada Gadget dan Pola Asuh Islami terhadap Mental Spiritual yaitu sebesar $5,5 \%$, sedangkan $94,5 \%$ pengaruh berasal dari faktor lain.

\section{Daftar Pustaka}

Anisah. (2011). Pola Asuh Orang Tua Dan Implikasinya Terhadap Pembentukan Karakter Anak. Jurnal Pendidikan Universitas Garut, 5(1), 70-84. 
Asuh, P., Orang, I., Dalam, T. U. A., Jiwa, M., Anak, S., Hidayati, F., Tarbiyah, F., Ilmu, D. A. N., Pendidikan, J., \& Islam, A. (2017). POLA ASUH ISLAMI ORANG TUA DALAM MENINGKATKAN JIWA SPIRITUAL ANAK (Study Kasus di RT 03 RW 13 Dusun Wawaran). 1-78.

Ayun, Q. (2017). Pola Asuh Orang Tua dan Metode Pengasuhan dalam Membentuk Kepribadian Anak. ThufuLA: Jurnal Inovasi Pendidikan Guru Raudhatul Athfal, 5(1), 102. https://doi.org/10.21043/thufula.v5i1.2 421

Benny, P., Aries, D., \& Samsul, H. (2019).

Bimbingan Orang Tua, Kedisiplinan dan Kosntribusinya Terhadap Pencegahan Perilaku Menyimpang. Shautut Tarbiyah, 25(2), 221-238.

Chusna, P. A. (2017). Pengaruh Media Gadget Pada Perkembangan Karakter Anak. Dinamika Penelitian: Media Komunikasi Sosial Keagamaan, 17(2), 315-330. https://e-

resources.perpusnas.go.id:2093/doi/abs /10.1142/S0192415X20500500

Darmawan, D. (2019). Berbagai Macam Metode Penelitian D. Darmawan. Journal of Chemical Information and Modeling, 53(9), 1689-1699.

Daulay, N. (2014). Pola asuh orangtua dalam perspektif psikologi dan Islam. Jurnal Darul Ilmi, 02(02), 76-91.

Febrino. (2017). Tindakan Preventif Pengaruh Negatif Gadget Terhadap Anak. Noura, 1(1), 1-21.

Firdausi, Z. (2017). Pengaruh Pendidikan Agama Islam dan Budaya Religius Sekolah Terhadap Kecerdasan Emosional dan Spiritual Siswa. Jurnal AlHikmah, 5(2), 46-55. http://www.jdi

Hardiyanto, S., Romadhona, E. S., Muhammadiyah, U., \& Selatan, T. (2018). REMAJA DAN PERILAKU MENYIMPANG (Studi Kasus Remaja di Kota Padangsidimpuan). Jurnal Interaksi: Jurnal Ilmu Komunikasi, 2(1), 23-32. http://jurnal.umsu.ac.id/index.php/intera ksi/article/view/1785

Iman, S., Nusa, A. K., \& Iman, M. S. (2020). Kesalehan ritual, sosial, dan spiritual. 7(2).

Kurniawati, D. (2020). Pengaruh Penggunaan Gadget terhadap Prestasi Siswa. Edukatif: Jurnal Ilmu Pendidikan, 2(1), 78-84. https://doi.org/10.31004/edukatif.v2i1.7 8

Mentari, M. (2020). Faktor Penentu Perilaku Keagamaan Siswa: Dampak Penggunaan Media Sosial Dan Pembelajaran. Oasis: Jurnal Kajian Islam, 4(2), 1-20.

Munte, S. A. (2013). Hubungan Pola Asuh Orang Tua dengan Perilaku Menyimpang Pada Remaja. 1-8.

Nur Utami, A. C., \& Raharjo, S. T. (2019). Pola Asuh Orang Tua Dan Kenakalan Remaja. Focus : Jurnal Pekerjaan Sosial, 2(1), 150. https://doi.org/10.24198/focus.v2i1.2313 1

Nurmalasari, \& Wulandari, D. (2018). Pengaruh Penggunaan Gadget Terhadap Tingkat Prestasi. Ilmu Pengetahuan Dan Teknologi Komputer, 3(2), 1-8.

Padjrin, P. (2016). Pola Asuh Anak dalam Perspektif Pendidikan Islam. Intelektualita, $\quad 5(1), \quad 1$. https://doi.org/10.19109/intelektualita.v $5 \mathrm{i} 1.720$

Prasetiya, B. (n.d.). No Title. 2(02). https://doi.org/10.29240/belajea.v4iL

Prasetiya, B. (2019). Analisis Studi Korelasional Kecerdasan Emosional dan Minat Belajar dengan Hasil Belajar Pendidikan Agama Islam. 5(2), 165-184.

Prasetyaningrum, J. (2012). Pola asuh dan karakter anak dalam perspektif Islam. Prosiding Seminar Nasional Psikologi Islam, 47-51.

Sampel, B., \& Nurlaila, C. (n.d.). Populasi, sampling.

. Su'ud, S. (2011). REMAJA DAN PERILAKU MENYIMPANG (Studi Kasus pada Masyarakat Boepinang, Bombana). Selami Ips, 1(34), 34-43.

Subarkah, M. A. (2019). Pengaruh Gadget Terhadap Perkembangan Anak. Rausyan 
Fikr: Jurnal Pemikiran Dan Pencerahan, Bondowoso. pada tahun 2008 lulus dari MA Al 15(1), 1689-1695. Marhamah. Pada tahun 2018, melanjutkan studi https://doi.org/10.31000/rf.v15i1.1374 kuliah pendidikan Islam di Sekolah Tinggi Islam Suliyanto. (2017). Pelatihan Metode Muhammadiyah Probolinggo untuk mendapatkan Pelatihan Kuantitatif. Journal of Chemical gelar sarjana Strata Satu. Saat ini bertempat Information and Modeling, 5(2), 223- tinggal di kota Probolinggo. Email: 232. ahmad.solehudin 1710.

Syahudin, D. (2019). Pengaruh Gadget Terhadap Pola Interaksi Sosial dan Komunikasi Siswa. GUNAHUMAS Jurnal Kehumasan, 2(1), 273-282.

Uyun, F. (2020). Pembinaan Mental Spiritual Masyarakat Kelompok Tahsin Kelurahan Sumbersari Kecamatan Lowokwaru Melalui Kajian Kritik Analitik Terhadap Kitab Al-Targhib Wa Al-Tarhib Dengan Pendekatan Komparatif Kontekstual. Journal of Research on Community Engagement, 2(1), 22-26. https://doi.org/10.18860/jrce.v2i1.795 5

Uyuni, Y. R. (2019). Konsep Pola Asuh Orang Tua Dalam Perspektif Islam Terhadap Tumbuh Kembang Anak Dalam Keluarga. As-Sibyan: Jurnal Pendidikan Anak Usia DiniJurnal Pendidikan Anak Usia Dini, 4(1), 53-64. http://jurnal.uinbanten.ac.id/index.php /assibyan/article/view/1964

Viandari, K. D., \& Susilawati, K. P. A. (2019). Peran pola asuh orangtua dan penggunaan gadget terhadap interaksi sosial anak prasekolah.

Jurnal Psikologi Udayana, 6(01), 76. https://doi.org/10.24843/jpu.2019.v06. i01.p08

Wig, N. N. (1999). Mental health and spiritual values. A view from the East. International Review of Psychiatry, 11(23), 92-96. https://doi.org/10.1080/09540269974 230

\section{PROFIL PENULIS}

Nama Ahmad Solehudin. Di lahirkan di Jember pada tanggal 10 April 1990. Pada tahun 2002 lulus SDN Langkap 4 Bangsalsari Jember. Tahun 2005 lulus dari MTS Al Aziz 